\title{
Contextualist Approaches and the Interpretation of the Qur'ān
}

\author{
Abdullah Saeed * and Ali Akbar \\ Asia Institute, University of Melbourne, Parkville, VIC 3010, Australia; ali.akbar@unimelb.edu.au \\ * Correspondence: a.saeed@unimelb.edu.au
}

check for

updates

Citation: Saeed, Abdullah, and Ali Akbar. 2021. Contextualist Approaches and the Interpretation of the Qur'ān. Religions 12: 527. https://doi.org/ $10.3390 /$ rel12070527

Academic Editor: Roberto Tottoli

Received: 24 May 2021

Accepted: 1 July 2021

Published: 13 July 2021

Publisher's Note: MDPI stays neutral with regard to jurisdictional claims in published maps and institutional affiliations.

Copyright: (c) 2021 by the authors. Licensee MDPI, Basel, Switzerland. This article is an open access article distributed under the terms and conditions of the Creative Commons Attribution (CC BY) license (https:/ / creativecommons.org/licenses/by/ $4.0 /)$.

\begin{abstract}
When it comes to the interpretation of ethico-legal texts in the Qur'ān, there is usually a high degree of emphasis on literalism and textualism but not enough focus on contextualization. This is true for both the classical period and the modern period. This article points to the contextual nature of interpretation and how the contextualist approach to interpreting the Qur'ān can enable Muslims to follow its ethical teachings in accordance with contemporary needs and circumstances, without sacrificing fundamental Qur'ānic values. In order to do so, the article refers to Qur'ānic passages related to freedom of religion and the laws of punishment, and explores how a contextualist approach to interpreting such passages may yield results different from those of a textualist or literalist approach.
\end{abstract}

Keywords: interpretation; tafsīr; ethics; legal verses; contextualist approach

\section{Introduction}

In the early periods of Islamic history, jurists developed a set of principles of jurisprudence ( $u s \underline{u}$ l al-figh) for the interpretation of different types of ethico-legal texts from the Qur'ān and the Hadith. Beginning with jurists such as Muhammad b. Idrīs al-Shāfi'i (d. $820 \mathrm{CE}$ ), Muslim scholars have attempted to systematize this legal thinking and have developed principles of jurisprudence for deriving laws from the Qur'ānic and Hadith texts (Gibb and Kramers 2001, pp. 552-54; Brown 1999). In developing the law and broadening it, these scholars have employed important tools such as qiyās (analogical reasoning) and a range of associated concepts. Thus, as this complex juristic tradition developed, an equally complex set of interpretive principles, ideas, beliefs, and practices emerged alongside it. The end result was a system of law that was relevant for their society and for the needs of that time (Vishanoff 2011, pp. 1-8; Saeed 2014, p. 70).

Traditionally, jurists have strongly emphasized textualism, particularly when reading ethico-legal texts. This is true not only for the classical period, but also for the modern period. Indeed, as some scholars have argued, textualism-which seeks to apply the Qur'ān's legal precepts in a literal form-has become popular among many Muslims today (Saeed 2014, pp. 180-82; Moosa 2003, p. 124; Gleave 2012, pp. 175-96). ${ }^{1}$ This article argues for a contextualist approach to the ethico-legal texts in the Qur'ān that are currently and have historically been associated with law and ethics. It explores why, how, and to what extent applying this approach to the Qur'ān is significant in the contemporary world.

\section{Modern Concerns about Relevance}

Throughout the modern period, some Muslim scholars have recognized that specific Qur'ānic texts may require reinterpretation today, given the difference between the political, social, economic, and cultural contexts of the modern world (i.e., the macro context of today) and those of the time of the Qur'ānic revelation. Muhammad Abduh (d. 1905) and Sayyid Ahmad Khan (d. 1898) were among the earliest thinkers in the modern period to argue for such a fresh approach to Qur'ānic interpretation. They called for a more flexible interpretation of some Qur'ānic texts and urged Muslims to stop blindly following traditional rulings. These thinkers, often referred to as "modernists," argued 
that the Qur'ān needed interpretation of a more contextual nature to make some of its teachings more compatible with modern realities and norms. They stressed the importance of reason and argued for interpreting the Qur'ān in light of contemporary scientific developments (Saeed 2014, pp. 21-22). Indeed, according to Abduh, God's guidance can only be understood when revelation is used alongside reason (Abduh 1960, p. 69).

Accordingly, Muhammad Asad, a twentieth-century commentator on the Qur'ān, reinterprets Qur'ānic texts concerning miracles with a particular focus on their spiritual meaning. For example, the miracles of healing lepers or the blind can be understood as demonstrations of the importance of spirituality, i.e., faith and guidance from God breathing new life into those who were "blind" to the truth or who suffered from spiritual diseases (Chande 2004, p. 82). This emphasis on reason has helped modernist scholars explore Qur'ānic teachings from a new perspective and with a strong focus on the realities of today.

Another line of thinking that emerged among modern-day thinkers was to bridge the gap between certain Islamic concepts and modern socio-political values by reinterpreting specific Qur'ānic terms. For example, unlike the vast majority of early commentators who did not provide a strongly political interpretation of the Qur'ānic verses concerning shürā (consultation) (3:159; 42:38) (Saeed 2014, pp. 149-51), Abduh interpreted it as a principle that might be followed to restrict a government's power to execute political decisions. Likewise, Rashid Rida argued that "democratic civility" is a reproduction of principles such as shürā and ijmāa (consensus), concluding that the Western-style parliamentary system is equivalent to the former. Central to this line of thinking was the identification of Qur'ānic verses concerning shürā that emphasized modern political norms, such as democracy, legislative parliament, and constitutionalism (Akbar 2020a, pp. 220-21).

\section{The Contextualist Approach}

Muslim theology holds that Qur'annic revelation is the communication of God's will to the Prophet Muhammad and, through the Prophet, to his community in the early seventh century CE. From a mainstream theological perspective, the angel Gabriel communicated God's Word to the Prophet in Arabic, and the Prophet and his community played no active role whatsoever in this process of revelation or in the formation of the Qur'ân. Therefore, although the Qur'ān is historically linked to the time when it was revealed, it is largely considered an eternal text that transcends history. This means that Muslim scholarship, generally speaking, has been reluctant to relate God's Word to the historical context in which the Qur'ān emerged. Many Muslim scholars consider the emphasis on an intimate relationship between the Qur'ān and its historical context to be a way of downplaying the revelatory nature of the Qur'ān (Esack 1997, p. 55). In this sense, classical Muslim scholars and commentators on the Qur'ān, when developing the disciplines of the occasion of the

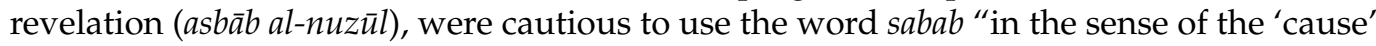
of God writing in the celestial tablet rather than the 'cause' of the verse being revealed into its historical circumstances (Rippin 1981, p. 30)". An emphasis on the influence of the Qur'ān's context on its content implied for many scholars that the Qur'ān is of human rather than divine origin (see Esack 1997, p. 15).

However, in the modern period, a number of Muslim thinkers, identified as "contextualist" scholars, have challenged the view that context is irrelevant to the revelation by emphasizing the close connection between the Prophet and his community (Rahman 2009, p. 100; Rahman 1982; Soroush 2000). Indeed, they consider the revelation to be closely linked to the Prophet, his feelings (including his likes and dislikes), his community, and the historical context in which the revelation occurred (Rahman 2009, p. 100; see also Rahman 1982, pp. 53-63; Abu Zayd 1990; Shahrur 2009). The key emphasis of the contextualist approach is the idea that the revelation took shape within the worldview of its first addressees, the broader context of Prophet Muhammad's life, and the values, norms, and practices of Hijaz society in the seventh century (See, for example, the works of (Abu Zayd 1990; Shahrur 2009; Saeed 2014, pp. 4-6). 
Abu Zayd is one such scholar who emphasizes the historicity of the revelation or its "occurrence in time" (al-hudūth fi-l-zamān) (Abu Zayd 1995, p. 71). For him, all religious scriptures, including the Qur'ān, are connected to the cultural norms of the societies in which they emerged (Abu Zayd 1992, p. 62). The Qur'ān, once revealed to the Prophet Muhammad, entered history and adjusted to the cultural values of Arabian society. Therefore, the Qur'ān is not only a "historical text" (nașṣ tārīkhì), but also a "product of culture" (muntaj thaqāfi) (See Abu Zayd 2006, p. 97; Abu Zayd 2000, p. 197). For Abu Zayd, the fact that the Qur'ann was revealed in Arabic, the language of the first recipients of the revelation, demonstrates that God adapted the revelation to the language, social situation, and cultural traditions of the Arabs of Muhammad's period (Abu Zayd 1990, pp. 11-12, 25-26). Another scholar, Mohsen Kadivar, takes a somewhat similar approach, arguing that the Qur'ān is a historically contextualized book and thus should be interpreted in light of the historical circumstances of its emergence. For him, Islam, like other religions, came into being within the limitations of its environment and era. Kadivar criticizes those who view the Qur'ān as a text that stands "beyond time and place," arguing that God's revelation became subject to all limitations, including being bound to history and society (see Kadivar 2008, pp. 37-40, 160).

Abdolkarim Soroush argues that through the mind of the Prophet, "revelation is adapted to its environment; it is also shaped in no insignificant measure by the Prophet's personal history, his life's tribulations and his state of mind during those twenty-three years or so" (Saeed 2014, p. 55). That is, cultural adaptation and even the psychological and spiritual state of the Prophet, including his feelings at different times, have left their mark on the Qur'ān. According to Soroush, all prophetic missions were influenced by the concepts that existed in the society of their day. Indeed, prophets could not invent concepts that did not yet exist, teach them to others, or ask people to use them (Soroush 2008).

To establish a link between the events that took place during the Prophet Muhammad's prophetic career and the Qur'ān, some contextualist scholars have argued that the message of the revelation changed along with the circumstances encountered by the Prophet and the nascent Muslim community. According to Abu Zayd, being essentially a dialogue that developed over the course of twenty-three years, the revelation had to be commensurate with all the different conditions its first recipients encountered (Kassab 2010, p. 188). In this sense, the Qur'ân reflects the relationship between the text and the realities of the nascent Muslim community, representing Muhammad's response to the needs of his community and the problems and issues the Muslims encountered (Abu Zayd 2010, pp. 287-88). Likewise, Soroush considers the historical genesis of the Qur'ân as being contemporaneous with its historical circumstances. According to Soroush, "some would go to the Prophet and ask him a question. Someone would insult the Prophet's wife. Someone would set alight the flames of war. Some would accuse the Prophet of being insane," and when the Prophet encountered such new conditions, new verses of the Qur'ān emerged in response to them. This meant that if other events had taken place or other questions had been posed to the Prophet, we would find different verses to those now in the Qur'ān-an idea which demonstrates the contextual nature of some Qur'ānic verses (Soroush 2009, pp. 16-17).

Therefore, the contextualist approach is historical in nature. It broadens interpretation to include more than linguistic analysis. Over the past few decades, some Turkish scholars, such as Mehmet Paçacı (b. 1959) and Ömer Özsoy (b. 1963), have also adopted such an approach. Like Soroush, Özsoy argues that some passages of the Qur'ān refer to particular events that took place in Muhammad's life-an idea that Özsoy uses to demonstrate "the necessity of reading the Qur'ān 'within' its own history (Korner 2005, p. 138)". For Özsoy, the reactions of the original addressees of the revelation significantly influenced the content of the Qur'ān. This means that the audiences of the Prophet were not passive per se, but played an important role in shaping the message of the Qur'ān. Özsoy refers to Qur'ān 5:101, which reads "O you who believe, do not ask about matters which, if made known to you, might make things difficult for you-if you ask about them while the Qur'ān is being revealed, they will be made known to you," to argue for the active role that Prophet 
Muhammad's audiences played in shaping the revelation. He suggests, "a process of open dialogue between the immanent and the transcendent" has occurred in Qur'ānic revelation (Korner 2005, p. 152).

Another theme found in the writings of contextualist scholars is that the context in which the Qur'ân is being interpreted should also be taken into consideration. This idea is often used by contextualists to argue that as time passes, new interpretations of the text, consistent with the norms and practices of the era, become possible (Saeed 2008, pp. 223-24). For example, Muhammad Shahrur declares that "just as in the seventh century people understood Allah's Book with the help of what was then contemporary knowledge, in the twenty-first century we must understand it with what is now contemporary knowledge." Shahrur concludes that it is only through a contemporary rereading of God's Book that "we succeed in achieving real reform and a successful renewal of Islamic thought" (Shahrur 2009, p. 2). Therefore, the Qur'ān can be interpreted anew in every age. Paçacı takes a similar approach, arguing that in the same way the historical context of the Qur'ann shapes its content, the historical environments of exegetes play a significant role in shaping their interpretive discourse. Referring to the hermeneutical term "the historicity of all understanding," he argues that "since the historical situations constantly change, the interpreters' manner of understanding will change [as well]" (Korner 2005, p. 79).

\section{The Importance of the Contextualist Approach in Today's World}

The contextualist approach can be applied to some ethico-legal texts that appear to be problematic in the contemporary context, especially when understood literally; for example, the Qur'ānic texts concerning certain criminal laws or those that seem to restrict the right to freedom of religion. The interpretation of texts related to these matters may present difficult challenges for many Muslims today if we do not take into account the context of the revelation and the context of today.

According to Soroush, Muslims today should recognize the historicity of the Qur'ānic revelation. Without this, they will struggle to obtain an understanding of the religion that is relevant to their contemporary context, or to determine which of its teachings are potentially changeable in today's world (Amirpur 2005, p. 345). Similarly, Kadivar argues that the Qur'ān includes changeable and unchangeable precepts that should be distinguished from each other. This is especially important in the modern period, where some rulings of the text seem to stand in sharp contrast to contemporary norms and values, such as those related to certain human rights. By establishing a close connection between the revelation and its original context, Kadivar paves the way for an interpretation of Qur'ānic texts that is responsive to changing circumstances (Kadivar 2009, p. 65). Along similar lines, Özsoy argues that although the "objective meaning" of the Qur'ān can be discovered by placing the text within its own history, Muslims today live in different circumstances. In light of this, some verses of the Qur'ān, especially those pertaining to some legal matters, ought to be interpreted differently (Wielandt 2016, p. 740). In what follows, we refer to two examples that demonstrate how the contextualist approach can be applied to certain ethico-legal texts of the Qur'ān.

\section{Examples of Contextualization: Two Cases}

\subsection{Freedom of Religion and Apostasy}

Several verses of the Qur'ān deal with the notion of apostasy-turning away from Islam to unbelief or to another religion. These texts severely condemn apostasy and warn apostates of punishment in the afterlife. They describe apostates as those whose deeds have become worthless in this world. According to the Qur'ân, they will reside in hell (2:217; see also 5:5 and 3:91). Some Qur'ānic verses describe apostates as having strayed from the right path $(2: 108 ; 4: 167)$. One verse describes them as being enticed by Satan (47:25), and another warns that they cannot expect God's forgiveness (4:137). The Qur'ān also says that apostates are cursed by God and the angels (3:87). 
Classical Muslim jurists commonly believed that, for a Muslim, nothing was worse than becoming a disbeliever (El-Awa 1982, p. 54). As El-Awa notes, "the common view among Muslim jurists ... is that apostasy from Islam is a crime for which the death penalty is prescribed" (El-Awa 1982, p. 50). It should be noted that since there is no Qur'ânic verse explicitly prescribing the death penalty for apostasy, early jurists "rarely attempted to demonstrate that the punishment for apostasy was based on the Quran" (Saeed and Saeed 2004, p. 57), but rather relied on a number of hadith to support their claim. Part of the reason for the convergence of opinion about the punishment associated with apostasy among classical scholars and jurists appears to be that they lived in a context that limited freedom of religion somewhat. When it came to matters related to freedom of religion, they listed verses of the Qur'ān such as Q 2:256-which states that there should be no compulsion in religion-as abrogated (Crone 2015). The ideas of classical scholars were consistent with societal norms that did not support freedom of religion in the way we understand it today. In the context of the twenty-first century, however, freedom of religion is a widely accepted norm and is present in many international covenants and declarations. For example, according to Article 18 of the Universal Declaration of Human Rights, "Everyone has the right to freedom of thought, conscience, and religion; this right includes freedom to change his religion or belief, and freedom, either alone or in community with others and in public or private to manifest his religion or belief in teaching, practice, worship and observance." (Universal Declaration of Human Rights 1948). Given the radical differences between the current macro context and that of early Islam, there are questions as to how apostasy and its punishment should be approached today. As will be demonstrated below, the contextualist approach provides a more realistic and applicable understanding of the relevant texts by taking into account their contexts, both at the time of the revelation and early Islam and in the modern period.

During the Meccan period of Prophet Muhammad's prophetic career, the Qur'ān insisted on absolute freedom of religion. This concept continued in the Medinan verses of the Qur'ān. Several verses (both Meccan and Medinan) state that everyone is free to accept Islam or reject it (see 18:29, 10:108, 9:41 and 27:91-3). Kadivar refers to Q 11:28, which deals with the narrative of Noah, noting that when Prophet Noah declared his prophethood he was confronted with resistance, yet he never forced the people to believe in his religion. ${ }^{2}$ During the Medinan period of Prophet Muhammad, although the basic notion of freedom of religion continued, an important new idea was added: "religious belief as a marker of inclusion within a political community" (Saeed 2012, p. 241). This meant that "Muslims became a religious and a political community" (Saeed 2012, p. 241). In this sense, membership in the nascent Muslim community was a significant matter for the Prophet, and Muslims were required to express their sense of belonging to the community. Therefore, turning away from Islam meant abandoning one's membership of the Muslim community, which could ultimately threaten the integrity, safety, and security of the community. It is important to note that even in such a context, the Qur'ān does not specify any worldly punishment for apostates, let alone capital punishment-as was later emphasized by jurists. Referring to Qur'ānic verses such as Q 2:217, Q 3:177, Q 3:86-7, Q 16:106, and Q 4:115, a number of contemporary Muslim scholars have argued that there is no worldly punishment prescribed for apostasy in the Qur'ān. Muhammad Abed al-Jabiri argues that the punishment for apostasy in the Qur'ān includes "a curse by God, His wrath, and hell but not execution" (Al-Jabri 2015, p. 198). Similarly, the Indonesian scholar Nurcholish Madjid argues that the Qur'ān does not prescribe any worldly punishment for the apostate. This means that "It is God, not the state [or people] that will pass judgment on apostasy and this judgment will come in a time of God's choosing" (Jones and Saeed 2006, p. 84).

Moreover, during the lifetime of the Prophet, apostates whom the Prophet ordered to be executed had committed other crimes, like murder. They were not simply executed for a mere change of belief (Saeed and Saeed 2004, pp. 62-64). In addition, the nascent Muslim community encountered dangers from various fronts, not only during the Prophet's life but also shortly after his death. In this context, turning away from 
Islam was perceived as weakening the Muslim community and thus equal to betrayal or treason. Indeed, in the context of the early period of Islam, in which the Muslim community was under threat from armed enemies-a condition referred to as "a state of war" by Madjid (Jones and Saeed 2006, p. 84) - "every Muslim was, in some, sense a soldier", and thus the punishment of a person leaving the community was naturally death (Jones and Saeed 2006, p. 84). This means that the traditional rulings on apostasy made sense in a specific condition and emerged "as a result of a specific interaction of event, circumstance, time and place" (Jones and Saeed 2006, p. 84). Al-Jabiri refers to the wars of apostasy (ridda) that occurred during the caliphate of Abu Bakr (d. 634) to further explain this context. According to him, apostates were fought and killed at that time, but not because of a simple change of faith. Rather, they posed a danger to society and the state. Indeed, the wars of apostasy were launched against those who attacked the Muslim state, not against those who simply changed their religion and did not join the enemy to attack the nascent Muslim community (Al-Jabri 2015, p. 199).

Taking the context related to the rulings on apostasy into consideration, what was punishable appears to be "collusion with the enemy or turning into a thief or enemy in arms," not a mere change of belief, al-Jabiri argues (Al-Jabri 2015, p. 199). Nasr Hamid Abu Zayd comes to a similar conclusion. According to him, conversion to another religion or to unbelief by itself does not call for any form of punishment. The act is punishable only when it is associated with aggression or hostility or when the perpetrator engages in violent acts against the state or society. Extrapolating this approach to the contemporary era, we can conclude that only those who renounce the Muslim community/state and become aggressors, conspirators, or spies, or those who engage in violent acts or in crimes such as murder or theft, should be subject to such punishment. Indeed, the punishment should not be applied to those who simply change their religion or turn to disbelief (Al-Jabri 2015, p. 199). For Abu Zayd, freedom of religion is guaranteed in the Qur'ān in verses such as Q 2:256. He claims that "the freedom to convert to another faith after accepting Islam ... is left to man's essential free choice" (Abu Zayd 2001). Today, we live in a context that is very different from that of the earliest Muslim community. Freedom of religion is now a widely accepted norm and can be found in many constitutions and domestic laws. In addition, those laws that were developed in early Islam based on the notion of an intimate relationship between religion and membership in the state no longer apply.

The same approach can be applied to some of the Qur'ānic verses about the People of the Book. Some verses in the Qur'ān contain polemic language against Jews and Christians (see 9:34; 4:161;5:13;5:18) and have been used by many textualist scholars to claim Islam's inherent superiority to Judaism and Christianity (for some examples, see Sirry 2014). This exclusivist approach has become even more overt today with the rise of violent extremist groups like al-Qaeda and, more recently, the so-called Islamic State of Iraq and Syria (ISIS). Qur'ānic verses such as these are often used by some Muslims to prevent or discourage Muslims from having positive social relations with people of other faiths (See Mohamed Bin Ali 2016).

From a contextualist perspective, Qur'ānic verses related to the relationship between Muslims and the People of the Book represent the conditions in which Prophet Muhammad and the Muslim community found themselves. As Munim Sirry argues, "the way in which the Qur'ān addresses the Jews and Christians of Medina corresponds to the various stages of ... the first community of believers" (Sirry 2014, p. 45). Whereas in the Meccan period the Qur'ān took a positive position vis-à-vis Jews and Christians, Medinan verses are marked by "a more polemical discourse" (Sirry 2014, p. 45). This discourse was contextual and emerged at the time when the Prophet Muhammad's conflicts with the Jews and Christians intensified and Islam sought to create a distinct religious community. Sirry notes that in this context, the Qur'ān responded to "the divergence of polemical statements that had been in the air for a while" (Sirry 2014, p. 55), meaning that "the sectarian milieu of Arabia in the early development of Islam contributed to the hardening of Muslim position against ... other monotheists like the Jews and Christians" (Sirry 2014, p. 60). 
Therefore, polemic verses about Jews and Christians should be understood as a result of the complex process of Islam's formation as a new religion, rather than general statements about them (Sirry 2014, p. 45). Such verses are contextual in the sense that they reflect the ongoing conflict between the nascent Muslim community and the Jewish and Christian communities in Arabia. Even in that context, the Qur'ān confirms the previous scriptures. Indeed, the Qur'an confirms that the Torah and the Gospel are scriptures revealed by God to prophets before Prophet Muhammad, not only in its Meccan verses, but also in Medinan passages. For instance, the Qur'ān states: “We have revealed to you as We revealed to Noah, and the prophets after him, and We revealed to Abraham, Ishmael, Isaac, Jacob, and the Tribes, Jesus and Job, Jonah and Aaron and Solomon, and We gave to David Psalms" (4:163; see also 2:42; 3:50; 5:46). Therefore, the Qur'ān's criticisms of certain elements of Judaism and Christianity should not be "understood as their complete abandonment by God" (Sirry 2014, p. 62). Moreover, even in the context of tensions and hostilities between Muslims and non-Muslims, the Qur'ān held that hatred of others should not prevent them from being treated justly (5:8), nor that the invitation to accept Islam should be undertaken by force or compulsion (see, for example, 10:99).

To sum up, the religious polemics found in some Qur'ānic verses are the result of a particular historical context, influenced by specific events throughout the course of Islam's formation as a new religion in the midst of paganism and other monotheistic religions-i.e., Judaism and Christianity. Continuing to apply them today-which could prevent Muslims from establishing positive social relations with people of other faiths-would indicate a misunderstanding of scriptural polemics in their original context. As Firestone states,

What is too often forgotten is the fact that every case of religious polemic occurs within a specific and limited historical context. Scriptural polemic inevitably records the tension and arguments of specific events and times early on in religious formation. Continuing to apply them to the current age is simply an error and misunderstanding of the role and meaning of scriptural polemics. (Firestone 2007, p. 53)

\subsection{Qur'ānic Laws Related to Punishment}

Texts related to the laws of punishment, such as retaliation (qișass ) or the amputation of the hand of a thief, also yield different results if a contextualist approach is adopted. According to the Qur'ān, the hand of a man or woman should be cut off as a punishment for theft (5:38). The Qur'ân provided this text at a time when societal conditions were different. In the context in which the Qur'ān emerged, this form of punishment was not considered unjust-it was already apparently widely accepted in the pre-Islamic era and seen as necessary for maintaining social order in the absence of a political authority or government which could control the society as a whole. As Abdelmadjid Charfi explains, amputation was consistent with a nomadic society whose structure was "based on subsistence economies" (Charfi 2003, p. 65). In this environment, it was natural that "theft should be punished severely, as this type of crime put the victim's very existence in jeopardy" (Charfi 2003, p. 66).

In many respects, the rise of Islam did not dramatically change the civic and social situation of the pre-Islamic era. The nascent Muslim community lived largely in a Bedouin context, and many laws that were developed to respond to the social situation of that era were simply transported into the legal system of the new religion (Al-Jabri 2015, p. 85). According to Muhammad Abed al-Jabiri, "in a Bedouin society, where the people move about with their tents and camels in search of pasture, it was not possible to penalize the thief by imprisonment" (Al-Jabri 2015, p. 85) due to the lack of jails or even walls or fences in the desert. There was no authority to guard the prisoner or to provide him or her with food and clothing. Thus, the only reasonable penalty for theft was corporal punishment, which could deter robbery, thereby guaranteeing social stability (Al-Jabri 2015, p. 85).

When Islam emerged as a new religion, an alternative punishment that could guarantee social stability was unavailable. Indeed, in keeping with prevailing social conditions, 
Islam did not introduce a new form of punishment. However, as Charfi argues, "when society evolves and adopts values in keeping with its evolution," new forms of punishment that recognize our inherent human dignity should be taken into account. This means, for him, that the punishment should not be conducted in such a way that our inherent human dignity is jeopardized. Today, other forms of punishment, such as incarceration, may be used instead. These punishments do not represent, in Charfi's opinion, a deviation from the spirit of the Qur'ān or the Prophet's teachings "as long as they fulfil the ultimate aim of guaranteeing social stability" (Charfi 2003, pp. 65-66). The form of punishment is therefore not fixed and eternal; rather, it is the purpose of the punishment that should remain unchanged. While under particular conditions amputating a thief's hand ensured social stability, in a new context another punishment may have the same result. In other words, based on the spirit of the Qur'ān, what can be claimed is that theft is punishable, but the type of punishment varies from time to time and from society to society.

Another punishment in the Qur'ān concerns retaliation (qișāss). The Qur'ān mentions qișaș in verses such as Q 5:45: "We prescribed for them a life for a life, an eye for an eye, a nose for a nose, an ear for an ear, a tooth for a tooth, an equal wound for a wound." Another verse states, "You who believe, fair retribution is prescribed for you in cases of murder: the free man for the free man, the slave for the slave, the female for the female" (2:178). Traditionalist scholars often consider qișass one of the necessary precepts of religion which should be implemented at all times and in all places. For example, according to Ayatollah Golpayegani-a contemporary Shia scholar- "if a Muslim questions the punishment of qișass, he is considered an apostate because he has denied a religious precept explicitly mentioned in the Qur'ān, a precept which is of the necessities of the religion" (Kayhan Magazine 22 May 1981).

In the era of the revelation, contextualists argue, qișass, in the form of taking a murderer's life, was the best way to resolve the debt between the tribes to which the murderer and the murdered belonged. In tribal societies like Arabia, killing a member of a tribe often led to an ongoing conflict between the two tribes, leading to bloodshed and innumerable losses of life. Therefore, the underlying logic behind qișās was to prevent individuals from sparking greater warfare. This is why the Qur'ān, in the last part of 2:179, indicates that there is life in qișass, meaning that its implementation will preserve life. According to the Qur'ān, no more than a single life should be taken for another. When discussing qișaș, the Qur'ân also emphasizes the principle of proportionality between the crime and the punishment (2:178). This was a response to "the pre-Islamic practice of tribal feuding and disproportionate retaliation for the killing of noblemen or tribal chiefs" (Abou El Fadl 2006). The idea that retaliation should be proportionate to the crime is also indicated in another verse: "if anyone commits aggression against you, attack him as he attacked you, but be mindful of God, and know that He is with those who are mindful of Him" (2:194). This verse warns believers against committing extra aggression and discourages them from taking a revenge greater than what they were afflicted with. This was also a response to the pre-Islamic context in which an aggregation resulted in disproportionate retaliation or the loss of many lives in retaliation for the murder of a single person. It is important to note that although the Qur'ān permitted Muslims to conduct qișașs, it strongly encouraged forgiving the offender in the same verses dealing with qișaș. Q $5: 45$ praises forgiveness in such a way that it is considered as atonement for a person's bad deeds: "if anyone forgoes this out of charity, it will serve as atonement for his bad deeds". Similarly, Q 2:178 encourages believers to forgive the culprit: "if the culprit is pardoned by his aggrieved brother, this shall be adhered to fairly, and the culprit shall pay what is due in a good way. This is an alleviation from your Lord and an act of mercy". This means that forgiveness and patience are moral virtues that are emphasized by the Qur'ān even in the context of tribal conflicts.

Abdelmadjid Charfi notes that "in the context of a tribal system and in the absence of state institutions, the family of the victim could take matters into their own hands." This often led to the loss of many lives. For Charfi, capital punishment in the form of qișass could 
be replaced by "imprisonment or other sanctions" in the modern context. Indeed, "there is no reason for not going further and abolishing capital punishment, especially in the complex setting of modern urban life" (Charfi 2003, pp. 63-65). Similarly, Muhammad Mujtahed Shabestari argues that since today's context is different from that of the Prophet's tribal society, qișass cannot be implemented as punishment for murder. For Shabestari, what must be taken into consideration in the case of qișa ș is the eternal value the Qur'ān sought to establish-i.e., the prohibition against excessive violence - not a fixed law that should be maintained at all times and in all places. In other words, while the underlying values or principles are fixed, the laws themselves are changeable, contextualists argue. The laws are there to achieve a particular result, i.e., the prevention of excessive violence. Therefore, the relevant law may be changed under different circumstances (Akbar 2020b, pp. 115-16), according to this view.

Such discussions constitute attempts to interpret verses contextually. In doing so, these scholars would argue that they are not attempting to "read into" the Qur'ānic text whatever they want. Rather, they are attempting to approach interpretation in a principled and methodologically sound manner.

\section{Concluding Remarks}

Analyzing ethico-legal Qur'ānic texts contextually enables Muslims to interpret and follow Qur'ānic teachings in a way that is practical and takes into account present-day circumstances and needs. It also makes some Qur'ānic ideas and concepts more adaptable to changing contexts. Contextualists would argue that this type of interpretation does not lead to the modification of fundamental values, beliefs, or Qur'ānic practices. It simply allows an interpreter to consider changing circumstances and contexts while interpreting certain Qur'ānic texts and, at the same time, retain the Qur'ān's fundamental teachings, which do not vary according to context. This article has attempted to show that the Qur'ānic texts on apostasy and corporal punishment are two instances where interpretation can change if a contextualist approach is adopted. Contextualist approaches to interpretation are relatively new and require further theorization and elaboration by contemporary Muslim scholars and thinkers. This article should be seen as a modest contribution to this effort, outlining various areas where a contextualist approach can contribute to the interpretation of the ethico-legal texts of the Qur'ān.

Author Contributions: Conceptualization, A.S. and A.A.; methodology, A.S. and A.A.; software, N/A.; validation, N/A.; formal analysis, A.S. and A.A.; investigation, A.S. and A.A.; resources, A.S.; data curation, N/A.; writing-original draft preparation, A.A.; writing-review and editing, A.A. and A.S.; visualization, N/A.; supervision, A.S.; project administration, A.S.; funding acquisition, A.S. All authors have read and agreed to the published version of the manuscript.

Funding: This research was funded by the Australian Research Council, grant number DP200100543.

Conflicts of Interest: The authors declare no conflict of interest.

\section{Notes}

1 The issue of context and reading the Qur'ān contextually is not new in modern scholarship on the Qur'ān. While scholars may differ on how they conceptualize "context," many works on the Qur'ān have used the idea of "context" as the basis for their works. Examples of Western scholarship include: (Scott 2009; Ernst 2013; Neuwirth et al. 2011).

2 For Kadivar's ideas about freedom of religion see (Akbar and Saeed 2020, pp. 147-49).

\section{References}

Abduh, Muhammad. 1960. Risālat al-tawhīd. Cairo: Wuzārat al-Thaqāfa.

Abou El Fadl, Khaled. 2006. Retaliation. In Encyclopedia of the Qur'ān. Edited by Jane Dammen McAuliffe. Leiden: Brill.

Abu Zayd, Nasr Hamid. 1990. Mafhūm al-Nass: Dirāsa fi 'Ulūm al-Qur'ān. Cairo: al-Hay'a al-Mișriyya al-'Amma li al-Kitāb.

Abu Zayd, Nasr Hamid. 1992. Naqd al-khitāb al-dīnī [Critique of Religious Discourse]. Cairo: Dār al-Thaqāfah al-Jadīdah.

Abu Zayd, Nasr Hamid. 1995. al-Nass, al-sulta, al-haqīqa: Al-Fikr al-dīnī: Al-Fikr al-dīn̄̄ bayna irādat al-marifa' wa irädat al-haymana. Beirut: Al-Markaz al-Thaqāīī al-'Arabī. 
Abu Zayd, Nasr Hamid. 2000. Divine Attributes in the Qur'ān: Some Poetic Aspects. In Islam and Modernity: Muslim Intellectuals Respond. Edited by John Cooper, Ron Nettler and Muhammed Mahmoud. London: I.B. Tauris Publishers, pp. $190-211$.

Abu Zayd, Nasr Hamid. 2006. Reformation of Islamic Thought: A Critical Analysis. Amsterdam: Amsterdam University Press.

Abu Zayd, Nasr Hamid. 2001. The Qur'ānic Concept of Justice. Available online: https://them.polylog.org/3/fan-en.htm\#s1 (accessed on 7 July 2021).

Abu Zayd, Nasr Hamid. 2010. The Others in the Qur'ān: A Hermeneutical Approach. Philosophy and Social Criticism 36: 2010. [CrossRef]

Akbar, Ali, and Abdullah Saeed. 2020. Contemporary Approaches to the Qur'ān and Its Interpretation in Iran. New York: Routledge.

Akbar, Ali. 2020a. Muslim reformist scholars' arguments for democracy independent of religious justification. Critical Research on Religion 8: 217-34. [CrossRef]

Akbar, Ali. 2020b. Contemporary Perspectives on Revelation and Qur'ānic Hermeneutics: An Analysis of Four Discourses. Edinburgh: Edinburgh University Press.

Al-Jabri, Muhammed Abed. 2015. Democracy, Human Rights and Law in Islamic Thought. New York: I. B. Tauris.

Amirpur, Katajun. 2005. The Changing Approach to the Text: Iranian Scholars and the Qur'ān. Middle Eastern Studies 41: 2005. [CrossRef]

Brown, Daniel. 1999. Rethinking Tradition in Modern Islamic Thought. Cambridge: Cambridge University Press.

Chande, Abdin. 2004. Symbolism and Allegory in the Qur'ān: Muhammad Asad's Modernist Translation. Islam and Christian-Muslim Relations 15: 79-89. [CrossRef]

Charfi, Abdelmadjid. 2003. Islam: Between Message and History. Translated by David Bond. Edinburgh: Edinburgh University Press.

Crone, Patricia. 2015. “No Compulsion in Religion": Q. 2:256 Mediaeval and Modern Interpretation. In The Qur'ānic Pagans and Related Matters. Patricia Crone. Leiden: Brill, pp. 351-409.

El-Awa, Mohamed S. 1982. Punishment in Islamic Law: A Comparative Study. Indianapolis: American Trust Publications.

Ernst, Carl W. 2013. How to Read the Qur'än. Chapel Hill: University of North Carolina Press.

Esack, Farid. 1997. Qur'ān, Liberation E Pluralism: An Islamic Perspective of Interreligious Solidarity Against Oppression. Oxford: OneWorld Publication.

Firestone, Reuven. 2007. The Way that New Religions Emerge. In Trialogue: Jews, Christians, and Muslims in Dialogue. New London: Twenty-Third.

Gibb, Hamilton Alexander Rosskeen, and Johannes Hendrik Kramers, eds. 2001. The Concise Encyclopaedia of Islam. Leiden: Brill. Gleave, Robert. 2012. Islam and Literalism: Literal Meaning and Interpretation in Islamic Legal Theory. Edinburgh: Edinburgh University Press.

Jones, Anthony H., and Abdullah Saeed. 2006. Nurcholish Madjid and the Interpretation of the Qur'ān: Religious Pluralism and Tolerance. In Modern Muslim Intellectuals and the Qur'ān. Edited by Suha Taji-Farouki. Oxford: Oxford University Press, pp. 67-96.

Kadivar, Mohsen. 2008. Haq al-nas: Islam va Huquq-e Bashar [The Right of People: Islam and Human Rights]. Tehran: Kavir Publication.

Kadivar, Mohsen. 2009. Human Rights and Intellectual Islam. In New Directions in Islamic Thought: Exploring Reform and Muslim Tradition. Edited by Kari Vogt, Lena Larsen and Christian Moe. New York: I. B. Tauris, pp. 47-73.

Kassab, Elizabeth S. 2010. Contemporary Arab Thought: Cultural Critique in Comparative Perspective. New York: Columbia University Press.

Korner, Flex. 2005. Revisionist Koran Hermeneutics in Contemporary Turkish University Theology: Rethinking Islam. Wurzburg: Ergon.

Mohamed Bin Ali. 2016. The Roots of Religious Extremism: Understanding the Salafi Doctrine of Al-Wala' wal Bara'. London: Imperial College Press.

Moosa, Ebrahim. 2003. The Debts and Burdens of Critical Islam. In Progressive Muslims on Justice, Gender and Pluralism. Edited by Omid Safi. Oxford: Oneworld, pp. 111-27.

Neuwirth, Angelika, Nicolai Sinai, and Michael Marx. 2011. The Qur'ān in Context: Historical and Literary Investigations into the Qur'ānic Milieu. Leiden: EJ Brill.

Rahman, Fazlur. 1982. Islam and Modernity. Transformation of an Intellectual Tradition. Chicago: Chicago University Press.

Rahman, Fazlur. 2009. Major Themes of the Qur'ān, 2nd ed. Chicago: University of Chicago Press.

Rippin, Andrew. 1981. The Qur'ānic asbāb al-nuzūl Material: An Analysis of Its Use and Development in Exegesis. Unpublished Ph.D. dissertation, McGill University, Montreal, QC, Canada.

Saeed, Abdullah, and Hassan Saeed. 2004. Freedom of Religion, Apostasy and Islam. Surrey: Ashgate.

Saeed, Abdullah. 2008. Some Reflections on the Contextualist Approach to ethico-legal texts of the Qur'ān. Bulletin of School of Oriental and African Studies 71: 221-37. [CrossRef]

Saeed, Abdullah. 2012. Pre-modern Islamic Legal Restrictions on Freedom of Religion, with Particular Reference to Apostasy and its Punishment. In Islamic Law and International Human Rights Law. Edited by Anver M. Emon, Mark S. Ellis and Benjamin Glahn. Oxford: Oxford University Press.

Saeed, Abdullah. 2014. Reading the Qur'ān in the Twenty-First Century: A Contextualist Approach. Oxon and New York: Routledge.

Scott, Rachel. 2009. A Contextual Approach to Women's Rights in the Qur'ān: Readings of 4:34. Muslim World 99: 60-85. [CrossRef]

Shahrur, Muhammad. 2009. The Qur'ān, Morality and Critical Reason. Translated by Andreas Christmann. Leiden: Brill.

Sirry, Mun'im. 2014. Scriptural Polemics: The Qur'ān and Other Religions. Oxford: Oxford University Press.

Soroush, Abdolkarim. 2000. Reason, Freedom, \& Democracy in Islam: Essential Writings of Abdolkarim Soroush. Edited by Mahmoud Sadri and Ahmad Sadri. New York: Oxford University Press. 
Soroush, Abdolkarim. 2008. Islam, Revelation and Prophethood. Available online: http:/ /www.drsoroush.com/English/Interviews / E-INT-Islam,\%20Revelation\%20and\%20Prophethood.html (accessed on 7 July 2021).

Soroush, Abdolkarim. 2009. The Expansion of Prophetic Experience: Essays on Historicity, Contingency and Plurality in Religion. Translated by Nilou Mobasser. Leiden: Brill.

Universal Declaration of Human Rights. 1948. 10 December. Available online: https://www.un.org/en/universal-declaration-humanrights / (accessed on 7 July 2021).

Vishanoff, David. 2011. The Formation of Islamic Hermeneutics: How Sunni Legal Theorists Imagined a Revealed Law. New Haven and Connecticut: American Oriental Society.

Wielandt, Rotraud. 2016. Main Trends of Islamic Theological Thought from the Late Nineteenth Century to Present Times. In The Oxford Handbook of Islamic Theology. Edited by Sabine Schmidtke. Oxford: Oxford University Press. 